\title{
Studi Perbandingan Pada Pembelajaran Menulis Melalui Media Video 3D Virtual Reality dan
}

\author{
Video 2D \\ Moris Virgiawan¹, Nunuk Suryani², Leo Agung Sutimin³ \\ morisv75@gmail.com
}

\begin{abstract}
This article presents the result of the research study aimed at finding out: (1) whether there is any significant difference in writing achievement between the students taught using 3D Virtual Reality video and those taught using $2 D$ video; and (2) whether the students taught using 3D Virtual Reality video have higher writing achievement than those taught using $2 D$ video. The research method used in this study is quasiexperimental research design. The research instrument used to collect the data in this study is writing test. The data were analyzed by using t-test formula. The computation of the $t$-test shows that $t$-observation $\left(t_{0}\right)=2.1028$ is higher than $t$-table $(58,0.05)=$ 2.0017. Therefore, it can be concluded that there is a significant difference in writing achievement between students taught using $2 D$ video and those taught using $3 D$ Virtual Reality video. The mean score of the experimental group improved from 67.56 to 76.55 , while the mean of the score of control group improved from 67.26 to 73.25 . The improvement of the experimental group is higher than the control group. It can be concluded that the students taught using 3D Virtual Reality video have higher writing achievement than those taught using $2 D$ video.
\end{abstract}

Keywords: $\quad 2 D$ video, 3D Virtual Reality video, writing skill

Abstrak: $\quad$ Artikel ini menyajikan hasil studi penelitian bertujuan untuk mengetahui: (1) Apakah ada perbedaan prestasi menulis yang signifikan antara siswa yang diajar menggunakan video 3D Virtual Reality dan mereka yang diajar menggunakan video 2D; dan (2) Apakah siswa yang diajar menggunakan video 3D Virtual Reality memiliki prestasi menulis lebih tinggi daripada siswa yang diajar menggunakan video $2 D$. Metode penelitian yang digunakan dalam penelitian ini adalah desain penelitian kuasieksperimental. Instrumen penelitian yang digunakan untuk mengumpulkan data dalam penelitian ini adalah tes menulis. Data dianalisis dengan menggunakan rumus t-test. Perhitungan t-test menunjukkan t-observasi (to) $=2,1028$ lebih tinggi dari t-tabel $(58,0,05)=2,0017$. Oleh karena itu, dapat disimpulkan bahwa ada perbedaan prestasi menulis yang signifikan antara siswa yang diajar menggunakan video $2 D$ dan siswa yang diajar menggunakan video 3D Virtual Reality. Nilai rata-rata dari kelompok eksperimen meningkat dari 67,56 menjadi 76,55, sedangkan rata-rata skor kelompok kontrol meningkat dari 67,26 menjadi 73,25. Peningkatan kelompok eksperimen lebih tinggi daripada kelompok kontrol. Dapat disimpulkan bahwa siswa diajarkan menggunakan video 3D Virtual Reality memiliki prestasi menulis lebih tinggi daripada yang diajarkan menggunakan video $2 D$.

Kata Kunci: Video 2D, 3D Video Virtual Reality, keterampilan menulis

\begin{tabular}{|c|c|c|}
\hline & Submitted: Oktober $2019 \quad$ Reviewed: Oktober 2019 & Accepted: Februari 2020 \\
\hline
\end{tabular}

\footnotetext{
1 Teknologi Pendidikan, Universitas Sebelas Maret

2 Teknologi Pendidikan, Universitas Sebelas Maret

3 Teknologi Pendidikan, Universitas Sebelas Maret
} 


\section{PENDAHULUAN}

D alam mata pelajaran bahasa Inggris, ada empat keterampilan bahasa yang harus dikuasai yaitu; mendengarkan (listening), berbicara (speaking), membaca (reading), dan menulis (writing). Mendengarkan dan membaca adalah keterampilan reseptif dimana pengguna dapat mencerna bahasa lisan maupun tulisan. Di sisilain, keterampilan berbicara dan menulis merupakan keterampilan produktif dimana pengguna bahasa dapat menghasilkan bahasa, baik lisan maupun tulisan

Sebagai keterampilan produktif, berbicara dan menulis pada dasarnya berbeda. Ketika kita berbicara, kita menggunakan intonasi, kenyaringan, kecepatan, ritme, jeda dan sebagainya yang membantu kita mendapatkan umpan balik dari pendengar tetapi hal ini tidak terjadi dalam hal penulisan di mana konteksnya dibuat melalui kata-kata saja dan tanpa interaksi langsung antara penulis dan pembaca (Bachani, 2004). Menulis adalah bagian integral dari komunikasi ketika orang lain tidak ada di depan kita, mendengarkan kata-kata kita dan melihat gerakan dan ekspresi wajah kita (Raimes, 1983). Dengan kata lain, menulis berbeda dari berbicara dalam konteks komunikasi. Berbicara dimaksudkan untuk komunikasi tatap muka antara pembicara dan pendengar secara langsung, sementara menulis digunakan oleh penulis untuk mengekspresikan dan mengkomunikasikan ide-ide mereka kepada pembaca yang dipisahkan oleh jarak, ruang, dan waktu. Oleh karena itu, diperlukan pesan yang lebih jelas dan lebih komprehensif untuk menghindari salah tafsir dari pembaca.

Secara umum, menulis adalah tindakan mentransfer ide-ide ke dalam bentuk tulisan. Menulis adalah proses berpikir untuk menemukan ide, berpikir tentang bagaimana mengekspresikan ke dalam tulisan yang baik, dan menyusun ide menjadi pernyataan dan paragraf dengan jelas (Nunan, 2003). Selain itu, menulis adalah kegiatan yang kompleks (Harris, 1993). Menulis menjadi kegiatan yang kompleks karena berhubungan dengan beberapa pengetahuan dasar seperti organisasi, penguasaan kosakata, tata bahasa, tanda baca, dan juga konten atau isi dari tulisan yang dibuat. Dari pernyataan-pernyataan itu, dapat disimpulkan bahwa menulis adalah proses kompleks untuk mengekspresikan ide-ide dari pemikiran penulis ke dalam bentuk tertulis dengan mempertimbangkan pengorganisasian, penguasaan kosakata, tata bahasa, tanda baca, dan juga konten untuk menyusun ide menjadi pernyataan dan paragraf yang dapat dimengerti.

Mengenai kompleksitasnya, keterampilan menulis sering dianggap sebagai keterampilan yang paling sulit untuk dikuasai karena memerlukan banyak aspek kebahasaan dalam produksinya seperti organisasi, konten, penggunaan bahasa, tanda baca dan kosa kata. Dari hasil wawancara terhadap siswa, peneliti menemukan bahwa kebanyakan dari siswa kesulitan dalam mengawali apa yang akan mereka tulis. Oleh karena itu, guru harus menstimulus siswa untuk menemukan ide dan memulai tulisan mereka.

Video dapat digunakan sebagai pemicu untuk bantuan guru dalam merangsang siswa sebelum menulis. Video dapat memberikan efek yang kuat pada pikiran dan indera (Berk, 2006). Selain itu, dengan menonton video, siswa memiliki kesempatan untuk menghasilkan ide-ide mereka dan mendapatkan lebih banyak inspirasi untuk menulis. Video sering digunakan untuk demonstrasi dan evaluasi, tetapi kami percaya bahwa pendekatan yang lebih produktif adalah dengan menggunakan video dan kemampuan guru untuk menafsirkanya dalam interaksi kelas (Sherin, 2009). Video merupakan gambar bergerak yang dapat menampilkan situasi, namun, apa pun bentuknya, video hanya dapat menampilkan gambar dua dimensi saja. Pengguna tidak dapat mengalami kondisi yang meyerupai keadaan sebenarnya. Hal ini menjadi titik lemah dari video, jadi video masih belum bisa membuat pesan atau materi secara maksimal. 
Media lain yang dapat uesd oleh guru untuk merangsang siswa sebelum kabel adalah video 3D Virtual Reality. virtual reality atau biasa disebut VR adalah teknologi video tiga dimensi yang memungkinkan pengguna untuk berinteraksi dengan lingkungan yang ada di dunia maya yang disimulasikan oleh komputer, sehingga pengguna merasa mereka berada di lingkungan itu. Virtual Reality (VR) adalah teknologi berbasis komputer yang menggabungkan khusus perangkat input dan output sehingga pengguna dapat berinteraksi secara mendalam dengan lingkungan virtual seolah-olah mereka di dunia nyata (Chandel \& Chauhan, 2014). Tujuan dari menggunakan video 3D Virtual Reality adalah untuk mencapai rasa yang kuat hadir dalam lingkungan virtual yang tampaknya sangat nyata (Linowes, 2015). Pengalaman tiga dimensi dirancang sebagai suplemen untuk rencana pelajaran tradisional guru, dengan memungkinkan siswa untuk melihat benda-benda yang terletak di kehidupan nyata mereka (Horn, 2017). Dengan menggunakan video 3D Virtual Reality, guru dapat membawa siswa mereka kemana saja ke seluruh dunia tanpa meninggalkan kelas, sehingga memberikan pengalaman yang lebih mengesankan dan memberikan inspirasi untuk menulis. Selain itu, video 3D Virtual Reality dapat memberikan konteks pembelajaran informal yang dapat mendukung pembelajaran yang diperoleh di ruang kelas. Selain itu, guru dapat mensimulasikan peristiwa mustahil dan berbahaya di kelas, sehingga menjadi momen yang menarik dan menyenangkan (Williams, Kapralos, Hogue, Murphy, \& Weckman, 2015). Namun, video 3D Virtual Reality mungkin membawa sejumlah ketidaknyamanan karena penggunaan headset Virtual Reality (Yildirim, 2017). Bahkan, ketika siswa tersebut memakai headset ini penglihatan dan pendengaran mereka bisa dibatasi hanya lingkungan virtual sehingga pengelolaan pengajaran di kelas melalui virtual reality bisa menjadi masalah. Maka dari itu, perlu dilakukan penelitian lebih lanjut apakah Media video 3D virtual reality dapat membatu siswa dalam meningkatkan kemampuan menulis atau justru menjadi penghambat dalam pembelajaran menulis.

\section{METODE PENELITIAN}

Peneliti memutuskan untuk menggunakan penelitian kuasi-eksperimental karena memungkinkan peneliti untuk mengidentifikasi hubungan kausal karena memungkinkan peneliti untuk mengamati, di bawah kondisi yang terkendali, efek sistematis mengubah satu atau lebih variabel (Johnson, Christensen \& Larry, 2012). Penelitian ini dilakukan di kelas XI SMA Batik 2 Surakarta dari 22 Agustus sampai dengan 24 September 2019, pada tahun akademik 2019/2020. Dua kelas yang digunakan sebagai sampel yang dipilih secara acak oleh peneliti dari sembilan kelas dari kelas XI di SMA Batik 2 Surakarta. Dua kelas tersebut adalah kelas XI IPA 3 yang terdiri dari 30 siswa sebagai kelompok eksperimen yang diajar menggunakan video 3D Virtual Reality dan XI IPA 4 yang terdiri dari 30 siswa sebagai kelompok kontrol yang diajar menggunakan video $2 \mathrm{D}$.

Dalam penelitian ini, peneliti melakukan try-out di mana hasilnya dianalisis dalam hal keterbacaan instruksi tes menulis. Try-out ini diujicobakan di salah satu kelas yang tidak termasuk dalam sampel penelitian tetapi di sekolah yang sama. Peneliti memilih kelas XI IPA 1 yang terdiri dari 34 siswa untuk melakukan tes try-out. Hal ini diperlukan karena ada beberapa kasus di mana siswa kesulitan untuk mengerjakan tes karena mereka tidak memahami instruksi yang diberikan.

Kelompok eksperimen dan kelompok kontrol diberi pre-test dengan menulis teks Recount. Setelah itu, kelompok eksperimen diajar dengan menggunakan video 3D Virtual Reality dan kelompok kontrol diajar dengan menggunakan video 2D sebagai media pembelajaran. Yang terakhir, kelompok eksperimen dan kelompok kontrol diberi post test dengan menulis teks Recount. Post-test dilakukan untuk membandingkan hasil dari kedua kelompok setelah mereka mendapat berbagai jenis video sebagai media pembelajaran.

Menulis tes, sebagai instrumen penelitian, yang digunakan oleh peneliti untuk mengukur prestasi menulis siswa untuk mengumpulkan data. Data yang dianalisis adalah skor pre-test dan post-test dari kelompok eksperimen dan kelompok kontrol. Data dibandingkan dengan menggunakan rumus t-test 
untuk membuktikan apakah ada perbedaan prestasi menulis yang signifikan antara kedua kelompok dan untuk menemukan media yang mana yang lebih efektif untuk pembelajaran menulis.

\section{HASIL DAN PEMBAHASAN}

Tujuan dari penelitian ini adalah untuk mengetahui: (1) Apakah ada perbedaan prestasi menulis yang signifikan antara siswa yang diajar menggunakan video 3D Virtual Reality dan siswa yang diajar menggunakan video 2D; dan (2) Kelompok manakah yang memiliki hasil yang lebih baik dalam menulis. Deskripsi data masing-masing kelompok disajikan sebagai berikut:

\section{Skor dari Grup Eksperimental}

Tabel 1: Distribusi frekuensi skor pre-test kelompok eksperimen

\begin{tabular}{clllll}
\hline $\begin{array}{c}\text { Interval } \\
\text { Kelas }\end{array}$ & Batas Kelas & Titik Tengah & Tabulasi & Frekuensi & Persentase \\
\hline $53-56$ & $52.5-56.5$ & 54.5 & I & 1 & 3.33 \\
\hline $57-60$ & $56.5-60.5$ & 58.5 & IIII & 4 & 13.33 \\
\hline $61-64$ & $60.5-64.5$ & 62.5 & III & 3 & 10.00 \\
\hline $65-68$ & $64.5-68.5$ & 66.5 & IIII IIII & 10 & 33.33 \\
\hline $69-72$ & $68.5-72.5$ & 70.5 & III & 3 & 10.00 \\
\hline $73-76$ & $72.5-76.5$ & 74.5 & IIIII III & 8 & 26.67 \\
\hline $77-80$ & $76.5-80.5$ & 78.5 & I & 1 & 3.33 \\
\hline & & & Total & 30 & 100 \\
\hline
\end{tabular}

Tabel 2: Distribusi frekuensi skor post-test kelompok eksperimen

\begin{tabular}{ccllll}
\hline $\begin{array}{l}\text { Interval } \\
\text { Kelas }\end{array}$ & Batas Kelas & Titik Tengah & Tabulasi & Frekuensi & Persentase \\
\hline $65-68$ & $64.5-68.5$ & 66.5 & IIII & 4 & 13.33 \\
\hline $69-72$ & $68.5-72.5$ & 70.5 & IIII II & 7 & 23.33 \\
\hline $73-76$ & $72.5-76.5$ & 74.5 & IIII I & 6 & 20.00 \\
\hline $77-80$ & $76.5-80.5$ & 78.5 & III & 4 & 13.33 \\
\hline $81-84$ & $80.5-84.5$ & 82.5 & IIII & 5 & 16.67 \\
\hline $85-88$ & $84.5-88.5$ & 76.5 & II & 2 & 6.67 \\
\hline $89-92$ & $88.5-92.5$ & 90.5 & II & 2 & 6.67 \\
\hline & & & Total & 30 & 100 \\
\hline
\end{tabular}

Skor tertinggi pre-test dari kelompok eksperimen adalah 77 sedangkan skor tertinggi post-test dari kelompok eksperimen adalah 91, sehingga perbedaan skor tertinggi pre-test dan post-test dari kelompok eksperimen adalah 14. skor terendah pre-test dari kelompok eksperimen adalah 53 sedangkan nilai terendah dari post-test dari kelompok eksperimen adalah 65 , sehingga perbedaan skor terendah pre-test dan post-test kelompok eksperimen adalah 12. skor rata-rata dari pre-test dari kelompok eksperimen adalah 67,56 sedangkan nilai rata-rata post-test dari kelompok eksperimen adalah 76,55 , sehingga perbedaan skor rata-rata pre-test dan post-test dari kelompok eksperimen adalah 8,99. 


\section{Skor dari Kelompok Kontrol}

Tabel 3: Distribusi frekuensi skor pre-test kelompok kontrol

\begin{tabular}{llllll}
\hline $\begin{array}{l}\text { Interval } \\
\text { Kelas }\end{array}$ & Batas Kelas & Titik Tengah & Tabulasi & Frekuensi & Persentase \\
\hline $54-57$ & $53.5-57.5$ & 55.5 & II & 2 & 6.67 \\
\hline $58-61$ & $57.5-61.5$ & 59.5 & III & 3 & 10.00 \\
\hline $62-65$ & $61.5-65.5$ & 63.5 & II & 2 & 6.67 \\
\hline $66-69$ & $66.5-69.5$ & 67.5 & IIIII IIII & 10 & 33.33 \\
\hline $70-73$ & $69.5-73.5$ & 71.5 & IIIII I & 6 & 20.00 \\
\hline $74-77$ & $73.5-77.5$ & 75.5 & IIII & 4 & 13.33 \\
\hline $78-81$ & $77.5-81.5$ & 79.5 & III & 3 & 10.00 \\
\hline & & & Total & 30 & 100
\end{tabular}

Tabel 4: Distribusi frekuensi skor post-test kelompok kontrol

\begin{tabular}{llllll}
\hline $\begin{array}{l}\text { Interval } \\
\text { Kelas }\end{array}$ & Batas Kelas & Titik Tengah & Tabulasi & Frekuensi & Persentase \\
\hline $62-65$ & $61.5-65.5$ & 63.5 & II & 2 & 6.67 \\
\hline $66-69$ & $65.5-69.5$ & 67.5 & IIIII & 5 & 16.67 \\
\hline $70-73$ & $69.5-73.5$ & 71.5 & IIIII III & 8 & 26.67 \\
\hline $74-77$ & $73.5-77.5$ & 75.5 & IIIII IIII I & 11 & 36.67 \\
\hline $78-81$ & $77.5-81.5$ & 79.5 & II & 2 & 6.67 \\
\hline $82-85$ & $81.5-85.5$ & 83.5 & I & 1 & 3.33 \\
\hline $86-89$ & $86.5-89.5$ & 87.5 & I & 1 & 3.33 \\
\hline
\end{tabular}

Skor tertinggi pre-test dari kelompok kontrol adalah 79 sedangkan skor tertinggi post-test dari kelompok kontrol adalah 86, sehingga perbedaan skor tertinggi pre-test dan post-test kelompok kontrol adalah 7. skor terendah pre -test dari kelompok kontrol adalah 54 sedangkan nilai terendah dari posttest dari kelompok kontrol adalah 62 , sehingga perbedaan skor terendah pre-test dan post-test kelompok kontrol adalah 8. skor rata-rata pre-test dari kelompok kontrol adalah 67,56 sedangkan nilai rata-rata 
post-test dari kelompok kontrol adalah 73,25 , sehingga perbedaan skor rata-rata pre-test dan post-test dari kelompok kontrol adalah 5.69 .

\section{Normalitas dan homogenitas dari Pre-test Kelompok Eksperimental dan Kontrol}

Uji normalitas yang digunakan dalam penelitian ini adalah Lilliefors yang menguji pada tingkat signifikansi 0,05 ( $\alpha=0,05$ ), sedangkan pengujian homogenitas digunakan rumus Bartlet pada tingkat signifikansi $0,05(\alpha=0,05)$. Hasil perhitungan uji normalitas pre-test untuk kelompok eksperimen dan control adalah berdistribusi normal. Dalam data kelompok eksperimen, dapat dilihat bahwa Lo adalah 0,043 . Hal ini kemudian dikonsultasikan dengan tabel $L$ untuk $n=30$ pada tingkat signifikansi $0,05=$ 0,159 . Dapat disimpulkan bahwa data kelompok eksperimen yang dalam distribusi normal karena nilai Lo lebih rendah dari $\mathrm{Lt}$ (Lo <Lt). Sementara itu, data dari kelompok kontrol menunjukkan bahwa Lo adalah 0,017 . Hal ini kemudian dikonsultasikan dengan tabel $L$ untuk $n=30$ pada tingkat signifikansi $0,05=$ 0,159 .

Dari perhitungan uji homogenitas pre-test, dapat dilihat bahwa $x 02=0,021$ lebih rendah dari $x t 2=$ 3,841 atau $x 02<x t 2$. Dapat disimpulkan bahwa data yang homogen karena x02 lebih rendah dari xt2.

\section{Normalitas dan homogenitas dari Post-test kelompok Eksperimen dan Kontrol}

Dari perhitungan uji normalitas post-test untuk kelompok eksperimen dan kontrol, dapat dilihat bahwa data dari kedua kelompok berdistribusi normal. Dalam data kelompok eksperimen, dapat dilihat bahwa Lo adalah 0,011 . Hal ini kemudian dikonsultasikan dengan tabel $L$ untuk $n=30$ pada tingkat signifikansi $0,05=0,159$. Dapat disimpulkan bahwa data kelompok eksperimen yang dalam distribusi normal karena nilai Lo lebih rendah dari Lt (Lo <Lt). Sementara itu, data dari kelompok kontrol menunjukkan bahwa Lo adalah 0.030 . Hal ini kemudian dikonsultasikan dengan tabel $L$ untuk $n=30$ pada tingkat signifikansi $0,05=0,159$. Dapat disimpulkan bahwa data kelompok kontrol yang dalam distribusi normal karena nilai Lo lebih rendah dari Lt (Lo <Lt).

Dari perhitungan uji homogenitas post-test, dapat dilihat bahwa $\chi 02=2,320$ lebih rendah dari $x \mathrm{t} 2=$ 3,841 atau x02 <xt2. Dapat disimpulkan bahwa data yang homogen karena xo2 lebih rendah dari xt2.

\section{Pengujian Hipotesis}

Peneliti menguji hipotesis nol $(\mathrm{Ho})$ dari penelitian bahwa tidak ada perbedaan prestasi menulis yang signifikan antara mereka yang diajar menggunakan video 3D Virtual Reality dan mereka yang diajar menggunakan video 2D sebagai media pembelajaran. Secara statistik, hipotesis dapat dirumuskan sebagai $\mathrm{Ho}=\mu 1=\mu 2$.

Hipotesis alternatif $(\mathrm{Ha})$ dari penelitian ini adalah bahwa ada perbedaan prestasi menulis yang signifikan antara mereka yang diajar menggunakan video 3D Virtual Reality dan mereka yang diajar menggunakan video 2D sebagai media pembelajaran. Secara statistik, hipotesis dapat dirumuskan sebagai $\mathrm{Ha}=\mu 1 \neq \mu 2$.

Hal ini diketahui bahwa jika to (to bservation) lebih rendah dari tt (ttabel), $\mathrm{H}_{0}$ diterima. Sebaliknya jika $t_{0}$ (to bservation) lebih tinggi dari $\mathrm{tt}$ (ttabel) atau $>\mathrm{tt}, \mathrm{H}_{0}$ ditolak.

Hasil t perhitungan menunjukkan bahwa untuk (tobservation) adalah 2,1028 sedangkan $\mathrm{tt}$ (ttabel) untuk derajat kebebasan 58 dan tingkat signifikansi $\alpha=0,05$ adalah 2,0017 begitu, untuk lebih tinggi dari tt (ttabel). Ini berarti bahwa Ho ditolak. Maka dapat disimpulkan bahwa bahwa ada perbedaan prestasi menulis yang signifikan antara mereka yang diajar menggunakan video 3D Virtual Reality dan siswa yang diajar menggunakan video 2D sebagai media pembelajaran. 
Hipotesis kedua dari penelitian ini adalah bahwa siswa yang diajar menggunakan video 3D Virtual Reality memiliki prestasi menulis lebih tinggi daripada siswa yang diajar menggunakan video 2D. Untuk menguji hipotesis kedua, penulis membandingkan peningkatan nilai antara pre-tes dan post-test dari kedua kelompok. Nilai rata-rata dari kelompok eksperimen meningkat dari 67,56 menjadi 76,55 , sedangkan rata-rata skor kelompok kontrol meningkat dari 67,26 menjadi 73,25. Peningkatan kelompok eksperimen lebih tinggi daripada kelompok kontrol. Dapat disimpulkan bahwa siswa yang diajar menggunakan video 3D Virtual Reality memiliki prestasi menulis lebih tinggi daripada yang diajar menggunakan video $2 \mathrm{D}$.

Hasil penelitian menunjukkan bahwa ada perbedaan prestasi menulis yang signifikan antara siswa yang diajar menggunakan video 3D Virtual Reality dan siswa yang diajar menggunakan video 2D. Penggunaan video 3D Virtual Reality menarik perhatian lebih dari para siswa dengan isinya. Para siswa diajar menggunakan video 3D Virtual Reality memiliki prestasi menulis lebih tinggi daripada yang diajarkan menggunakan video 2D. Para siswa memberikan pendapat positif terhadap penggunaan 3D video yang Reality Virtual di kelas. Para siswa berpikir bahwa video 3D Virtual Reality mempermudah dan memotivasi mereka. Mayoritas siswa merasa 3D Video Virtual Reality menyenangkan dan efektif karena bisa menyajikan menciptakan perasaan keterlibatan seperti dalam lingkungan yang sesungguhnya. Terutama, beberapa fitur teknologi VR seperti kemudahan penggunaan, antarmuka yang ramah pengguna dan peluang memberikan hasil positif pada siswa. Temuan ini mengkonfirmasi penelitian terkait sebelumnya yang terutama menekankan perasaan realitas dan keterlibatan yang disediakan video 3D Virtual Reality (Dong, 2016).

\section{KESIMPULAN DAN SARAN}

Berdasarkan hasil penelitian dan pembahasan, ada perbedaan prestasi menulis yang signifikan antara siswa yang diajar menggunakan video 3D Virtual Reality dan siswa yang diajar menggunakan video 2D. Siswa diajar menggunakan video 3D Virtual Reality memiliki prestasi menulis lebih tinggi daripada yang diajarkan menggunakan video $2 \mathrm{D}$.

Penulis menyarakan agar penggunaan media video 3D Virtual Reality dapat diterapkan di jenjang pendidikan yang berbeda untuk menyelidiki di jenjang apa media video 3D Virtual Reality dapat memberikan hasil terbaik.

\section{DAFTAR PUSTAKA}

Bachani, M. (2004). Teaching Wriitng. 1-4. Retrived on August 22, 2019. waymadedu.org StudentSupportTeaching\%20Writing.pdf.

Raimes, A. (1983). Techniques in Teaching Writing. New York: Oxford University Press.

Nunan, D. (2003). Practical English Language Teaching. Singapore: Mc Graw Hill

Harris, J. (1993). Introducing Writing. London: Penguin English.

Berk, Ronald A. (2009) Multimedia Teaching with Video Clips: TV Movies, YouTube, and mtv in the College Classroom. International Journal of Technology in Teaching and Learning, 5(1), 1-21.

Sherin, M. G., Linsenmeier, K. A., \& van Es, E. A. (2009) Issues in the design of video clubs: selecting video clips for teacher learning. Journal of Teacher Education, 60(3), 213-230.

Chandel, Deepak \& Chauhan, Akshit. (2014) Virtual Reality. International Journal of Science and Research, 13 (10), 2319-7064

Linowes, J. (2015) Unity Virtual Reality Projects. Birmingham: Packt Publishing Ltd.

Horn, Michael B. (2017). Virtual Reality Disruption ProQuest.16, (4), 1 - 4 
Williams-Bell, F. M., Kapralos, B., Hogue, A., Murphy, B. M., \& Weckman, E. J. (2015). Using serious games and virtual simulation for training in the fire service: a review. Fire Technology, 51(3), 553584.

Yildirim, G. (2017). The Users'views on Different Types of Instructional Materials Provided in Virtual Reality Technologies. European Journal of Education Studies, 3(11). 150-171.

Johnson, Burke., Christensen, Larry. (2012). Educational Research: Quantitative, Qualitative, and Mixed Approaches (4th ed.). California: SAGE publications, inc.

Dong, X. (2016). An overall solution of Virtual Reality classroom. In Service Operations and Logistics, and Informatics (SOLI), 2016 IEEE International Conference (pp. 119-123). IEEE. 